\title{
CELESTINA AND THE MAGICAL EMPOWERMENT OF WOMEN
}

\author{
Dorothy Sherman Severin \\ The University of Liverpool
}

\section{Celestina's Witchcraft in its European Context}

Celestina was written shortly after the Malleus Malificarum (Hammer of the Witches, 1484) which was to inspire a series of important sixteenth- and seventeenth-century witch persecutions. Although the importance of sorcery in the work has been recognized since Peter Russell's seminal article of $1963,{ }^{1}$ in which he pointed out that Celestina performed philocaptio upon Melibea, the full implications of this theme are only just beginning to be examined.

Witchcraft was not a particularly hot topic in Spain at the end of the fifteenth century. The Inquisition, however, was, and the persecution concentrated not on witches for their imagined sins or real practices, but on the conversos for their Judaizing, again sometimes real and sometimes imagined. Rojas paints a very ambivalent picture of Celestina, and she seems, at times, both hero and villain of the piece. Her sorcery or witchcraft is also ambivalent and difficult to judge. On the one hand she deals in love magic or white magic, but on the other she summons demonic forces to help her when she casts a spell. Because witchcraft was not the object of official persecution, it is possible to infer from all of this an extended metaphor for the Jewish persecutions, and some of the specific 
references to the Inquisitional tribune of Celestina's mentor, Claudina, bear this out (see below). Indeed, one might even suggest that Celestina herself is a symbolic figure representing conversos since she appears to be genuinely making a pact with the Devil and summoning up evil. However, I do not propose to examine this point, but rather follow a different track, namely that the alternative anti-paternalistic society of empowered women and weak men which she creates is at the same time seductive and destructive.

Christine Lerner's definitions of witchcraft and sorcery can be of use when trying to determine Celestina's status as a witch or sorceress. ${ }^{2}$ According to Lerner, 'compact witchcraft' or a pact with Satan, blurs the distinction between black (harming) and white (healing) witchcraft. Sorcery (incantation and the manipulation of objects) is frequently harmless, while its use for malificium is witchcraft. The latter was usually punishable by death in the Middle Ages.

Celestina's spell includes the calling up of Satan and an apparent pact with the Devil, thereby straying from the realms of sorcery into that of witchcraft. This is an obviously vital distinction. The characters are careful to always call Celestina 'hechicera' or sorceress (they would not relish the accusations of consorting with a witch or 'bruja'). While Celestina discusses in detail the one time that her mentor Claudina was accused of being a witch, because she was caught gathering earth at a crossroad, Celestina's description of Claudina's torture and the priest's consolation ('Blessed are those who suffer persecution for righteousness sake') ${ }^{3}$ is followed by a silence about Claudina's fate (see below). Celestina herself was publicly punished with Claudina for sorcery on one occasion and Claudina herself was arrested three more times for sorcery and once for witchcraft.

Although Celestina has escaped being tried as a witch, the other characters are decidedly ambivalent about her status. Sempronio crosses himself when he sees her (103), Pármeno maligns her to Calisto in Act I, and even Lucrecia is unable to speak her name (88-89). ${ }^{4}$ More than once they refer to her scarface, the sign of the Devil. They may call her 'hechicera' but they treat her as 'bruja'.

Curiously, Celestina appears in a hiatus in the witchcraft trial activity in Europe, ${ }^{5}$ although the Malleus had appeared shortly before 
the probable date of composition of the anonymous first act of Celestina, with its descriptions of Celestina's laboratory. Moreover, Spain was never a focal point of witchcraft trials because of the Inquisitional concentration on the conversos, but there were significant trials in the Basque country in the seventeenth century which mirrored the more frenzied activities elsewhere in Europe in the sixteenth and early seventeenth centuries. The increasing importance of witchcraft persecutions seems to have gone hand in glove with religious reform, and certainly had as its target women who had power in their communities, as healers, midwives, cosmeticians, bawds, and at times sorceresses and witches (although we now rightly question the efficacy of the latter). As there were no objective proofs of this efficacy, witchcraft was a crimen exceptum for which torture and trials by ordeal were acceptable.

The main lines of critical argument have been drawn between those who believe that Celestina has real power which operates in the work and those who think that her psychological manipulation of the other characters can explain all her success and that the witchcraft is mere ego-boosting. ${ }^{6}$ The late fifteenth century was demonstrably both religious and superstitious, and although some doubt has been cast on Rojas' traditional Christian values, at least at the time when he wrote Celestina, he is unlikely to have been totally immune to the beliefs of his age. Certainly, it is difficult to explain the opportune departure of Melibea's mother Alisa to tend a sick relative and the memory lapse about Celestina's identity which delivers Melibea into the bawd's hands in Act IV, except by invoking the long arm of coincidence. It is demonstrable that Celestina thinks that the Devil has created these opportunities, and Rojas even augments her asides to the Devil in Tragicomedia interpolations, just in case the reader has missed the point. Peter Russell was the first to delve into this theme seriously and to point out the role of philocaptio. He mentions that Celestina is a sorceress not a witch and elaborates upon this opinion in his recent edition of the work. ${ }^{7}$ Pármeno's statement ' $y$ todo era burla y mentira' at the end of his description of the laboratory has been variously explained by Russell, who also points out that it was written by the first author. Julio Caro Baroja has stated in a recent article $^{8}$ that while the power of witches was thought to be real, the Devil was considered a deceiver, so that despite the real power of the Devil through the witches, this was at the same time a deception. 
Alan Deyermond's work on witchcraft in the text of Celestina ${ }^{9}$ is particularly fruitful. He examines how the Devil enters the skein of thread when Celestina casts her spell, and then moves on to Melibea's girdle which Celestina procures for Calisto and her own witchcraft purposes, and then on to the gold chain with which Calisto rewards Celestina. In the process the Devil infects everyone who touches these items and creates the final tragedy. An excellent summary of the witchcraft theme in Celestina is available in Patrizia Botta's recent article.

There are two main points to be made about witchcraft in Celestina. The first has been noted by Russell, Deyermond and others. Celestina unleashes a force of evil with her diabolic pact which is stronger than she suspects and which leads not just to love but to death. Love, which Calisto makes his God at the beginning of the work, by the end of the work is the Enemy who has destroyed all whom s/he touched.

The second point has only been noted in passing by some critics. ${ }^{10}$ Witchcraft, sorcery, and bawdry empower Celestina in her society and make her the dominant character not just in the work but in her social milieu. This world-upside-down means that Celestina threatens the patriarchal order represented by Pleberio and finally destroys it.

Rojas as a man and a believer (even if not a wholehearted Christian) condemns this usurpation of male prerogatives; he could have done so under the influence of Mosaic law which expressly forbids witchcraft:

Regard not them that have familiar spirits, neither seek after wizards, to be defiled by them. I am the Lord your God. (Lev. 20.51)

And the soul that turneth after such as have familiar spirits and after wizards, to go awhoring after them, I will ever set my force against that soul, and will cast him off from among his people. (Lev. 21.6)

Or even more boldly: 'Thou shalt not suffer a witch to live' (Exodus 22.18). 
So whether or not Rojas was a 'good' Christian, he would have been aware of the force of these interdictions, so recently reinforced by Malleus Malificarum. However although he shows what happens if the social order is challenged by women, as a marginalized figure himself he also paints a curiously seductive view of this new world order, and adds some new material to the expanded Tragicomedia so that the reader or listener can appreciate the emergence of Melibea, Areúsa and Elicia after Celestina's death. In the figure of Celestina he creates the most important female witch of the late Middle Ages.

\section{A Textual Overview}

When Pármeno describes Celestina to Calisto in Act I, he lists her trades variously as seamstress, perfumer and cosmetician, restorer of virgins and bawd, and occasionally sorceress. To these one can add folk-healer and midwife, and possibly witch. There is no doubt that she is an enchantress or 'hechicera' but she also seems to make a pact with the Devil on at least one occasion which would make her a witch according to contemporary definitions of witchcraft. She admits that her old mentor, Claudina, Pármeno's mother, was accused of witchcraft because she was found gathering dust from a crossroads--a typical liminal witches' venue where they were said to gather to meet spirits. Claudina had definitely been caught and publicly shamed on various occasions for her sorcery; if the accusation of witchcraft was upheld at a trial it would have been a capital crime. However the death is left unexplained:

CEL. -Hijo, digo que sin aquélla, prendieron cuatro veces a tu madre, que Dios haya, sola. $\mathrm{Y}$ aun la una le levantaron que era bruja, porque la hallaron de noche con unas candelillas, cogiendo tierra de una encrucijada, y la tuvieron medio día en una escalera en la plaza puesta, uno como rocadero pintado en la cabeza ...

PARM. -Verdad es lo que dices; pero eso no fue por justicia.

CEL. -... Poco sabes de achaque de iglesia y cuánto es mejor por mano de justicia que de otra manera. Sabíalo mejor el cura, que Dios haya, que viniéndola a consolar, dijo que la santa Escritura tenía que bienaventurados eran los que padecían 
persecución por la justicia, y que aquéllos poseerían el reino de los cielos. Mira si es mucho pasar algo en este mundo por gozar de la gloria del otro. Y más que, según todos decían, a tuerto y [a] sinrazón y con falsos testigos y recios tormentos la hicieron aquella vez confesar lo que no era ... Así que todo esto paso tu buena madre acá, debemos creer que le dará Dios buen pago allá, si es verdad lo que nuestro cura nos dijo y con esto me consuelo.

Although Celestina enthusiastically regales Pármeno with descriptions of her own training and the exploits of the two sorceresses, she is silent on the topic of witchcraft, as well she might be, for the sake of her own safety.

In the first scene of the work Calisto has encountered Melibea in her garden in pursuit of his hawk and has been rebuffed by her. He returns to his own house in an ill-temper, first to upbraid Sempronio and then to praise Melibea to the skies, declaring that he is not a Christian but a Melibean who worships the lady:

CAL. - ¿Yo? Melibeo soy y a Melibea adoro y en Melibea creo y a Melibea amo. (50)

CAL. - ¿Que me repruebas?

SEMP. -Que sometes la dignidad del hombre a la imperfección de la flaca mujer.

CAL. - ¿Mujer? ¡Oh grosero! ¡Dios, dios!

SEMP. - ¿Y así lo crees? ¿O burlas?

CAL. - ¿Que burlo? Por dios la creo, por dios la confieso y no creo que hay otro soberano en el cielo; aunque entre nosotros mora.

SEMP. - (¡Ha, ha, ha! ¿Oístes qué blasfemia? ¿Vistes qué ceguedad?) (51)

This heresy leaves Calisto open to the Devil's work when Sempronio immediately seizes upon a plan to make himself a good profit from Calisto's lust. The Celestina whom Sempronio approaches with his proposal to supply Calisto with Melibea at considerable cost is an aged crone with a scar on her face--the mark of the Devil. But bad luck awaits her at Calisto's house since she will be seen at the door by her old charge Pármeno, who knows her schemes better than 
anyone, and who regales Calisto with a description of Celestina's laboratory and witchcraft paraphernalia:

\begin{abstract}
PÁRM. - ¡Sí, santo Dios! Y remediaba por caridad muchas huérfanas $y$ criadas que se encomendaban a ella; y en otro apartado tenía para remediar amores y para se querer bien. Tenía huesos de corazón de ciervo, lengua de víbora, cabezas de codornices, sesos de asno, tela de caballo, mantillo de niño, haba morisca, guija marina, soga de ahorcado, flor de yedra, espina de erizo, pie de tejón, granos de helecho, la piedra del nido del águila, y otras mil cosas. Venían a ella muchos hombres y mujeres y a unos demandaba el pan do mordían; a otros, de su ropa; a otros de sus cabellos; a otros, pintaba en la palma letras con azafrán; a otros, con bermellón; a otros, daba unos corazones de cera, llenos de agujas quebradas y otras cosas en barro y en plomo hechas muy espantables al ver. Pintaba figuras, decía palabras en tierra. ¿Quién te podrá decir lo que esta vieja hacía? Y todo era burla y mentira. (62)
\end{abstract}

Although Pármeno proves easy to corrupt with the promise of Areúsa, Melibea will be another story. Celestina decides that this is a task for her magical powers, and she pulls out all the stops for this occasion. Back in her own house she has Elicia fetch some magic items, namely a skein of thread, some snake oil, some papers from an ark written on in bat's blood and some goat's blood with a few of its whiskers. Although the exact use of all these is not known, since we must always infer the action from the dialogue and there are no descriptive passages, Celestina seems to draw a magic circle. These generally are used either to contain or exclude the Devil. Presumably in this case she protects herself by standing within the circle. She then invokes the Devil with the classical epithet 'triste Plutón', and threatening him with revenge if he does not obey her will and subject Melibea to her power, she concludes: ' $Y$ otra y otra vez te conjuro; [y] así confiando en mi mucho poder, me parto para allá con mi hilado, donde creo te llevo ya envuelto' (85-86).

She proceeds to dip the skein of thread in the snake oil and to cast a philocaptio spell by which Melibea's love will be captured 
when she buys this skein from Celestina, according to Peter Russell (1963). Celestina then seems to pledge herself to the Devil which she had conjured up--if he does this then he can ask what he will of her. If not, she curses him. She then proceeds to Melibea's house, and along the way perceives that her auguries are good--three of the men in the street are called John, two of them are cuckolds, and no black birds in sight:

Todos los agüeros se aderezan favorables o yo no sé nada de esta arte. Cuatro hombres, que he topado, a los tres llaman Juanes y los dos son cornudos. La primera palabra que oí por la calle, fue de achaque de amores. Nunca he tropezado "como otras veces. Las piedras parece que se apartan y me hacen lugar que pase. $\mathrm{Ni}$ me estorban las haldas ni siento cansancio en andar. Todos me saludan. Ni perro me ha ladrado ni ave negra he visto, tordo ni cuervo ni otras nocturnas. $\mathrm{Y}$ lo mejor de todo es que veo a Lucrecia a la puerta de Melibea. Prima es de Elicia; no me será contraria. (87)

Sure enough, when she arrives not only does Melibea's mother Alisa completely forget who she is, although they used to live in the same neighbourhood (Celestina having now gone down in the world and Alisa up), but Alisa even is called away to attend a sick relative and she leaves Melibea unattended in Celestina's care. However, Celestina doesn't in fact make very much headway at first with Melibea who seems bloody minded when Calisto's name is mentioned. But Celestina calls to the Devil in an aside:

MEL. ... ¡Jesú, Jesú! ¡Quítamela, Lucrecia, de delante, que me fino, que no me ha dejado gota de sangre en el cuerpo! Bien se lo merece esto y más, quien a estas tales da oídos. Por cierto, si no mirase a mi honestidad y por no publicar su osadía de ese atrevido, yo te hiciera, malvada, que tu razón y vida acabaran en un tiempo.

CEL. - (iEn hora mala acá vine, si me falta mi conjuro! ¡Ea pués! Bien sé a quién digo. ${ } \mathrm{Ce}$, hermano, que se va todo a perder!) (95) 
Celestina retrieves the situation by insisting that all she wants is for Melibea to write her a prayer to Saint Appolonia in order to help cure Calisto of a toothache--a typical courtly lover's malady ${ }^{11}$-and of course she asks for a piece of clothing, Melibea's sash or girdle, her cordón, as an amulet:

CEL. - Una oración, señora, que le dijeron que sabías de Santa Apolonia para el dolor de las muelas. Asimismo tu cordón, que es fama que ha tocado [todas] las reliquias que hay en Roma y Jersualén. Aquel caballero, que dije, pena y muere de ellas. Ésta fue mi venida. Pero, pues en mi dicha estaba tu airada respuesta, padézcase él su dolor, en pago de buscar tan desdichada mensajera. Que, pues en tu mucha virtud me faltó piedad, también me faltará agua, si a la mar me enviara. Pero ya sabes que el deleite de la venganza dura un momento y el de la misericordia para siempre. (97)

When Melibea buys the skein of thread and surrenders her sash, the enchantment begins to take effect. The Devil moves from the skein to the girdle and when Calisto fondles it in Act VI, he too will be infected by the Devil, according to Alan Deyermond.

I however wish to suggest that something even more extraordinary is going to happen. Celestina's profession has always empowered her in her own society. She is fiercely proud of her past importance, although it is now on the wane. On more than one occasion she regales us with a portrait of herself when she was in her prime:

CEL. - ¿El primero, hijo? Pocas vírgenes, a Dios gracias, has tú visto en esta ciudad que hayan abierto tienda a vender, de quien yo no haya sido corredora de su primer hilado. En naciendo la mochacha, la hago escribir en mi registro, y esto para que yo sepa cuántas se me salen de la red. ¿Qué pensabas, Sempronio? ¿Habíame de mantener del viento? ¿Heredé otra herencia? ¿Tengo otra casa o viña? ¿Conócesme otra hacienda, más de este oficio? ¿De qué como y bebo? ¿De qué visto y calzo? En esta ciudad nacida, en ella criada, manteniendo honra como todo el mundo sabe, ¿conocida pues, no soy? 
Quien no supiere mi nombre y mi casa, tenle por estranjero. (81)

She sees herself 'maintaining honour' in the town and describes how she ran an extensive prostitution ring and bawdy house for the entire community, especially for the clergy, including the nuns. The communion bread would even end up in her house along with many other gifts from the clergy, and if she entered a church all eyes would be on her. Finally, anyone who didn't know her would be ashamed to admit it:

... Pues servidores, ¿no tenía por su causa de ellas? Caballeros viejos [y] mozos, abades de todas dignidades, desde obispos hasta sacristanes. En entrando por la iglesia, veía derrocar bonetes en mi honor, como si yo fuera una duquesa. El que menos había de negociar conmigo, por más ruin se tenía. De media legua que me viesen, dejaban las Horas. Uno a uno [y] dos a dos, venían a donde yo estaba, a ver si mandaba algo, a preguntarme cada uno por la suya. [Que hombre había, que estando diciendo misa], en viéndome entrar, se turbaban, que no hacían, ni decían cosa derechas. Unos me llamaban señora, otros tía, otros enamorada, otros vieja honrada. Allí se concertaban sus venidas a mi casa, allí las idas a la suya, allí se me ofrecían dineros, allí promesas, allí otras dádivas, besando el cabo de mi manto y aun algunos en la cara, por me tener más contenta. Agora hame traído la fortuna a tal estado, que me digas: "¡Buena pro hagan las zapatas!" (151)

In short, Celestina was the lord of misrule in her own town. She was empowered by her many professions but especially by her traffic in sex. Again a pact with the Devil is inferred from the circumstances. Celestina exchanges her female powerlessness for a power based on magic and lust, but her power has begun to slip badly; she has only a shadow of her former importance now. Calisto represents a way for her to make a lot of money and to reassert her importance as a go-between. ${ }^{12}$ But it all goes fatally wrong. After her second interview with Melibea, when she is called to aid the now love-sick girl in her capacity as folk-doctor, and when she arranges an interview between Calisto and Melibea at the garden gate. Celestina 
starts to make a fatal mistake. When she reports her successes to Calisto and rushes away with her booty, a gold chain, she loses all sense of discretion and tries to cut Sempronio and Pármeno out of the deal.

According to Deyermond this is because the Devil has now entered Calisto's gold chain and affects Celestina's good sense. After the rather chaste first interview between Calisto and Melibea at the garden gate, Sempronio and Pármeno go to Celestina's house and kill her for the booty: their blind avarice and violence suggest that too seem to have been infected by the Devil in the chain. But I do not believe that the power of the Devil stops here.

When Celestina visits Melibea for the second time Melibea is being eaten alive by the poisonous snake of desire. Celestina's death is followed by two nights of love making between Calisto and Melibea and an apparent empowering of Melibea, who has previously behaved as a typically over-protected daughter of the wealthy merchant class. In their first garden encounter when Calisto brings along a ladder to gain access to the garden, Calisto virtually rapes Melibea who tries to keep him from forcing himself upon her. Despite her lament at the loss of virginity she seems keen to arrange further assignations which allegedly take place over a month, although we will only witness the last of these. But in between assignations there is an extraordinary scene in which Melibea overhears her father Pleberio and mother Alisa discussing a possible marriage for her. Melibea enraged, declares her freedom from the bonds of convention:

... En pensar en él me alegro, en verlo me gozo, en oírlo me glorifico. Haga y ordene de mí a su voluntad. Si pasar quisiere la mar, con él iré; si rodear el mundo, lléveme consigo; si venderme en tierra de enemigos, no rehuiré su querer. Déjenme mis padres gozar de él, si ellos quieren gozar de mí. No piensen en estas vanidades ni en estos casamientos; que más vale ser buena amiga que mala casada. Déjenme gozar mi mocedad alegre, si quieren gozar su vejez cansada; si no, presto podrán aparejar mi perdición y su sepultura. No tengo otra lástima sino por el tiempo que perdí de no gozarlo, de no conocerlo, después que a mí me sé conocer. No 
quiero marido, no quiero ensuciar los ñudos del matrimonio, ni las maritales pisadas de ajeno hombre repisar, como muchas hallo en los antiguos libros que leí o que hicieron más discretas que yo, más subidas en estado y linaje. (206)

¡Afuera, afuera la ingratitud, afuera las lisonjas y el engaño con tan verdadero amador, que ni quiero marido ni quiero padre ni parientes! Faltándome Calisto, me falte la vida, la cual, porque él de mí goce, me aplace. (207)

She does not wish to step in the marital footsteps of another man, as Calisto is her soul and her life. If he wishes to cross the sea she will go with him, or will even let him sell her into bondage in Moorish lands. These more fanciful fates show the influence of popular songs and ballads in Melibea's imagination. But her declaration of independence from the fate chosen by her parents shows something else--that Melibea too has been empowered by the demonic forces of lust that have entered her. She becomes the dominant partner in the love affair. Celestina's power has passed to her.

What then of Calisto? After the death of his servants he shows the craven side of his nature and rather than face public mockery--since his dealings with Celestina have become public knowledge--he goes into hiding in his own house and pretends to be away while really carrying on with Melibea at night. It is Melibea's turn, particularly in the second garden scene, to invest her lover with imagined angelic qualities and to make him her god:

MELIB. - ¡Oh sabrosa traición, oh dulce sobresalto! ¿Es mi señor de mi alma? ¿Es él? No lo puedo creer. ¿Dónde estabas, luciente sol? ¿Dónde me tenías tu claridad escondida? ¿Había rato que escuchabas? ¿Por qué me dejabas echar palabras sin seso al aire, con mi ronca voz de cisne? Todo se goza este huerto con tu venida. Mira la luna cuán clara se nos muestra, mira las nubes cómo huyen. ¡Oye la corriente agua de esta fontecica, cuánto más suave murmurio y zurrío [y ruzio] lleva por entre las frescas hierbas! Escucha los altos cipreses, cómo se dan paz unos ramos con otros por intercesión de un 
templadico viento que los mena. Mira sus quietas sombras, cuán escuras están y aparejadas para encubir nuestro deleite. (222)

CAL. - Jamás querría, señora, que amaneciese, según la gloria y descanso que mi sentido recibe de la noble conversación de tus delicados miembros.

MELIB. - Señor, yo soy la que gozo, yo la que gano; tú, señor, el que me haces con tu visitación incomparable merced. (223)

Elicia and Areúsa are not quiet either. They have already shown their extraordinary ill will and envy of Melibea in Act IX, the servants banquet, and now vow to take their revenge on her. whom they blame for the deaths of their lovers Sempronio and Pármeno. Elicia has never been much good as a sorceress' apprentice and feels her loss of revenue particularly strongly. She curses the lovers and their garden--Celestina's power seems to have passed to Melibea:

... ¡Oh Calisto y Melibea, causadores de tantas muertes! ¡Mal fin hayan vuestros amores, en mal sabor se conviertan vuestros dulces placeres! Tórnese lloro vuestra gloria, trabajo vuestro descanso. Las hierbas deleitosas, donde tomáis los hurtados solaces, se conviertan en culebras, los cantares se os tornen lloro, los sombrosos árboles del huerto se sequen con vuestra vista, sus flores olorosas se tornen de negra color. (201)

Just in case the curse doesn't work, Areúsa from spite enlists the help of her pimp Centurio, a braggart warrior figure, who vows to sort out Calisto and his stable lads Tristán and Sosia in the street. In the event, he's not brave enough even for this and he bribes a friend to give the lads a fight. However the Devil once unleashed by Celestina's spell and Elicia's curse will not sit still. Calisto, in an uncharacteristic act of bravura, hears the altercation outside the garden walls and in his haste to help the lads, he falls to his death from his ladder. His ignominious death would have been hushed up had Melibea been able to endure her fate. But again she decides to act as a free agent and choose her own death by throwing herself from the tower of her father's house, after explaining the situation to Pleberio. Pleberio is left alone over the lifeless body of his daughter 
and the senseless body of his wife, lamenting his fate and cursing the power of love:

... Dulce nombre te dieron; amargos hechos haces. No das iguales galardones. Inicua es la ley que a todos igual no es. Alegra tu sonido; entristece tu trato. Bienaventurados los que no conociste o de los que no te curaste. Dios te llamaron otros, no sé con qué error de su sentido traídos. Cata que Dios mata los que crio; tú matas los que te siguen. Enemigo de toda razón, a los que menos te sirven das mayores dones, hasta tenerlos metidos en tu congojosa danza. Enemigo de amigos, amigo de enemigos, ¿por qué te riges sin orden ni concierto? Ciego te pintan, pobre y mozo. Pónente un arco en la mano, con que tires a tiento; más ciegos son tus ministros, que jamás sienten ni ven el desabrido galardón que sacan de tu servicio. Tu fuego es de ardiente rayo, que jamás hace señal do llega. La leña que gasta tu llama, son almas y vidas de humanas criaturas, las cuales son tantas, que de quien comenzar pueda, apenas me ocurre. No sólo de cristianos, mas de gentiles y judíos y todo en pago de buenos servicios. (235-36)

Love becomes the Enemy (or the Devil) and leads the world in its own Dance of Love and Death to an Inferno of lovers. The Devil's power has not necessarily disappeared. It may now simply have reverted to Elicia, the witch's apprentice. If she had lost the Devil's power she will regain it after the deaths in the garden.

I see in all this Rojas' creation of a subversive society, a world upside-down where women are empowered and men are weak. The Devil empowers his client Celestina who runs a society which consists initially of herself and Elicia but then reaches out in concentric circles to include first Areúsa, then Pármeno and Sempronio and Calisto himself, from Calisto's household, then Lucrecia and Melibea from Pleberio's household. Thus the natural order of patriarchy, GodPleberio-Areúsa-Melibea-Lucrecia, is absorbed into the world of women's misrule. Despite his many complaints of orthodoxy in the introductory material of the work, the converso Rojas seems to take a 
perverse pleasure in his alternative society of witchcraft, lust and greed run riot.

\section{Conclusion: A World of Women}

As Gilman intuited in his introduction to my Alianza edition of the text, Celestina is a work about urban domesticity which largely takes place within the walls of people's houses--or their walled gardens, the urban version of the locus amoenus. He finds the domesticity of Celestina and Elicia one of the few compensations for Rojas' bleak view of life, love and death. But inner space is women's space, as the author makes quite clear. Celestina's house, once flourishing in the red light district, now moved and much diminished, ${ }^{13}$ is at the same time a bawdy house, a factory for perfumes and cosmetics, and a symbol of the misrule of a woman empowered by her illegal professions of sorceress, witch and bawd. Celestina's space encroaches on the patriarchal space of the other characters as she increasingly dominates their houses as well. She visits Calisto's house; he becomes increasingly reclusive until by the end of the work he is trapped in his house, unable to leave except by night when he visits Melibea in her garden. Celestina visits Pleberio's house; Alisa is driven away by witchcraft and the bawd becomes 'madre Celestina'. ${ }^{14}$ Melibea takes possession of her own space outside Pleberio's house, the garden which he had planted, which becomes her secret kingdom and a bridgehead for her declaration of freedom from the constraints of patriarchal domination. She seizes and scales the phallic tower of the garden and symbolically takes her own life by jumping from it.

Areúsa too, the other liberated woman of the work, has her own space from which she manages to eject her pimp Centurio. 'En mi pequeña casa, exenta y señora', 'me vivo sobre mí, desde que me sé conocer' $(150,149)$ she claims proudly in the banquet scene of Act IX, a line echoed by Melibea in Act XVI when she declares her independence from her parents' plans for her future--'No tengo otra lástima sino por el tiempo que perdí de no gozarlo, de no conocerlo, después que a mí me sé conocer' (206).

Yet this world of liberated women is a world of misrule. It has been caused by the actions of one man, Calisto, who declared himself a heretic whose god was his lady Melibea. The Devil, overhearing Calisto's impieties, goes to work through Sempronio. 
Celestina, once involved in the plot, conjured up the Devil whose name in this story becomes both the Enemy and Love: 'enemigo de toda razón... Enemigo de amigos, amigo de enemigos, ¿por qué te riges sin orden ni concierto?' (236-37). Lust, greed and even shame about the past in Pármeno's case, all continue to unleash a series of deaths which leave only Pleberio, Elicia and Areúsa as surviving major characters (Lucrecia, Centurio, Tristán and Sosia being bit players). Pleberio by his own admission is finished, but by leaving Elicia and Areúsa alive as Celestina's heirs, Rojas has furnished ammunition for the Celestinesque genre to follow, as well as the female picaresque novel in the line of La Lozana Andaluza, La picara Justina, and finally the English picaresque tradition.

Rojas' basic intuition and the brilliance of the work lie in the fact that Evil can be very attractive, even when personified by an ugly old bawd. Celestina is the evil genius of the work, but her spirit of anarchy seeps into all of the liberated women of the work. Melibea and Areúsa are tremendously attractive in their desire to be free from the chains that bind them to patriarchal society. Although I have always firmly set my face against any notion that there is a secret message about conversos concealed in the work and that any single character is secretly a converso, a more convincing argument can be made for a marginalized Rojas identifying with these female characters who wish to overthrow the oppressive patriarchy of their society. Within the bounds of what seems to be a rigid orthodoxy, in which only an acute pessimism and the lack of any mention of the afterlife could seem to suggest the influence of his Jewish ancestry, Rojas creates an attractive alternate society of female industry and female sexual liberation. Sex and money mean freedom and power to Celestina and her female acolytes, and that money far exceeds its intrinsic value for her. And although Melibea seems to be giving sex away for free, she too harbours the illusion that Calisto will liberate her from her captivity and run away with her to Moorish lands if necessary.

Of course these are all illusions. The female characters are all beggared by circumstance. Celestina has lost much of her importance and livelihood because of a change in the laws regarding prostitution in late fifteenth-century Spain (see Lacarra above). Elicia is frank about her dependence on Celestina. Areúsa is prey to pimps like Centurio, although she represents the new face of free-lance prostitution. And Melibea deludes herself; Calisto, a coward if ever 
there was one, is not even interested in asking for her hand in marriage, much less in abandoning his status as a local señorito for her benefit.

At the end of the day, the female characters basically must fall back on one another for comfort and companionship, Elicia on Celestina and Areúsa, Melibea on Lucrecia. Elicia is the least deluded in this respect; she recognizes her dependence on Celestina and knows that she isn't much use as a sorceress' apprentice. She feels the loss of Celestina most keenly, both as 'madre' and breadwinner, and when she sees that her mourning is driving away the goodwill factor that attaches to Celestina's old dwelling, she is quick to shed it. A naturally dependent character, she turns to Areúsa for comfort and protection. It is the self-styled independent woman Areúsa who will proclaim that her art is different from that of Celestina. A newstyle prostitute, she'll set up shop alone--a category of free enterprise that was still tolerated after the local city governments took over the public houses of prostitution (Lacarra).

These two are the survivors of Celestina--presumably, along with Lucrecia their cousin, who one imagines would be shown the door by Pleberio after his daughter's death. The two main female protagonists do not survive to the end of the tale. Celestina has been killed by her own courage which degenerated into foolhardiness, not presumably simply because of greed but because the spell she cast had taken possession of her. Melibea's prophecy that her life would end with Calisto's has been self-fulfilling. Like Calisto she made Love her God and he proved to be the Devil. She is the true victim in the work as her prayers have failed to protect her and her Christian charity was turned against her. This I find the most unorthodox aspect of the text. Surely her devotion should have been a protection against the Devil but she seems to succumb rapidly to the Devil in the skein--and to Celestina and Calisto's blandishments. By the end of the work, apparently bereft of orthodox Christian faith despite a last prayer to God, Melibea commits suicide and condemns herself to the flames of Hell, where presumably she hopes to find Calisto ('Espera, que tras ti voy'). As Deyermond has pointed out, ${ }^{15}$ she may well not find him there since he called for confession before his death.

Celestina's rebellion has failed. Empowered by the Devil to do his dirty work in the name of Love, she has had a fair amount of success and importance in her life, but in the end it kills her. The 
women she touches also become empowered--only briefly in the case of Melibea, but perhaps more lastingly in the cases of Elicia and Areúsa. Elicia basically hates Celestina's black arts--'Yo tengo odio a este oficio, la mueres tras ello' she says, referring not only to the mending of virgins but to the whole profession. Some of Celestina's prestige may remain with Elicia if she plies her trade in prostitution, but the sorcery and witchcraft seem to die with her. Elicia's effective curse on Melibea's garden is her only hint that Celestina's black arts may find a new practitioner.

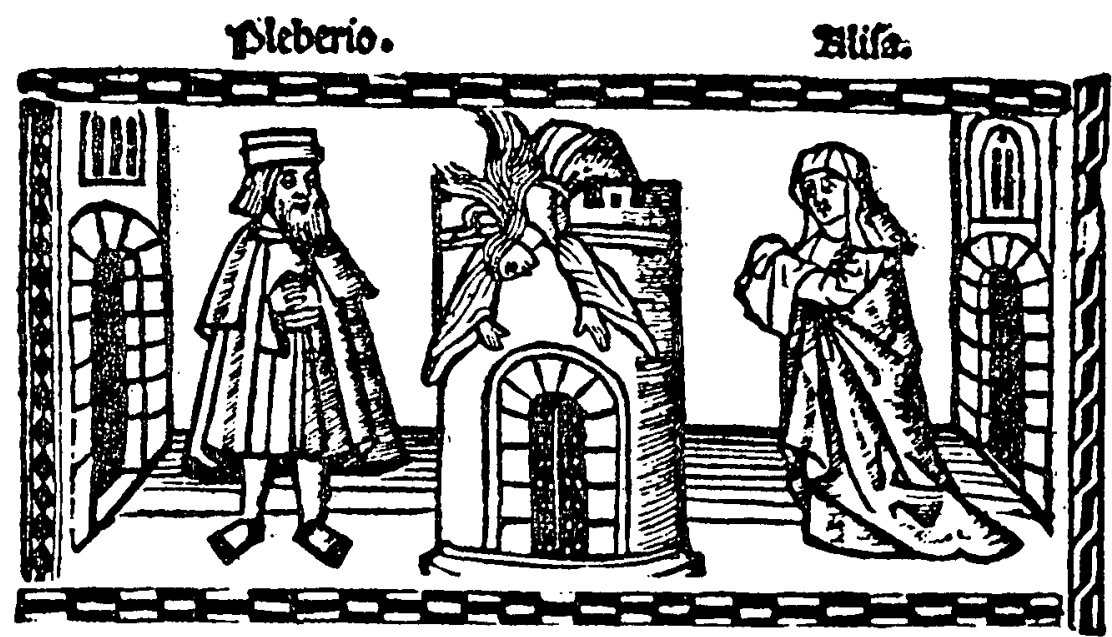

Valencia 1514. Grabado del $21^{\circ}$ aucto. 


\section{NOTES}

1 Peter E. Russell, 'La magia como tema integral de La Celestina', Studia Philologica: Homenaje a Dámaso Alonso (Madrid: Gredos, 1963), III, 337-54; 2nd ed. in Russell, Temas de 'La Celestina' y otros estudios, del 'Cid' al 'Quijote' (Barcelona: Ariel, 1978), 243-76.

${ }^{2}$ Christine Lerner, Witchcraft and Religion: The Politics of Popular Belief (Oxford: Blackwell, 1984).

${ }^{3}$ Stephen Gilman, 'Matthew 5.10 in Castilian Jest and Earnest', in Studia Hispanica a honorem R. Lapesa (Madrid: Cátedra, 1972), 1, 257-65.

${ }^{4}$ All references are to my Alianza edition, Madrid, 1969 etc.

5 Richard Kieckhefer, European Witch Trials: Their Foundations in Popular and Learned Culture: 1300-1500 (London: Routledge, 1976); also Magic in the Middle Ages (Cambridge: University Press, 1989).

${ }^{6}$ See Patrizia Botta, 'La magia en La Celestina: status quaestiones', in Magia, alquimia y astrología en la Edad Media. Actas de los Cursos de Verano de la Universidad Complutense, Almería, 29 de julio-2 de agosto, 1991, ed. Nicasio Salvador Miguel (Madrid: Universidad Complutense, forthcoming).

${ }^{7}$ (Madrid: Castalia, 1991), 67-76.

8 Julio Caro Baroja, 'Witchcraft and Catholic Theology' in Early Modern European Witchcraft, ed. B. Ankerloo and G. Henningsen (Oxford: Clarendon, 1990), 17-43.

9 Alan Deyermond, '"Hilado-cordón-cadena": Symbolic Equivalence in La Celestina', Celestinesca, 1.1 (Mayo 1977), 6-12.

${ }^{10}$ For example, Stephen Gilman, The Spain of Fernando de Rojas: The Intellectual and Social Landscape of 'La Celestina' (Princeton: University Press, 1972), 357-93.

11 Geoffrey West, 'The Unseemliness of Calisto's Toothache', Celestinesca, 3.1 (Mayo 1979), 3-10. 
12 Francisco Márquez Villanueva, Orígenes y sociología del tema celestinesco (Barcelona: Anthropos, 1993).

${ }^{13}$ See María Eugenia Lacarra, Cómo leer 'La Celestina' (Madrid: Júcar, 1990), 23-29. See also the same author's 'La evolución de la prostitución en la Castilla del siglo XV y la mancebía de Salamanca en tiempos de Fernando de Rojas,' in Fernando de Rojas and 'Celestina': Approaching the Fifth Centenary, ed. Ivy A. Corfis and Joseph T. Snow (Madison: HSMS, 1993), 33-78. Also see Peter Russell, 'Why did Celestina Move House?', in The Age of the Catholic Monarchs, 14741516. Literary Studies in Memory of Keith Whinnom (Liverpool: Liverpool University Press, 1989), 155-61.

${ }^{14}$ Jane Hawking, 'Madre Celestina', Annali dell'Istituto Universitario Orientale, Sezione Romanza, 2 (1967), 177-90.

${ }^{15}$ Alan D. Deyermond, '”iMuerta soy! ¡Confesión!": Celestina y el arrepentimiento a la última hora', in De los romances villancicos a la poesía de Claudia Rodríguez... homenaje a Gustav Siebenmann, ed. J.M. López de Abiada and A. Lopez Berna Soech (Madrid: J.E. Estiban, 1984), 129-40.

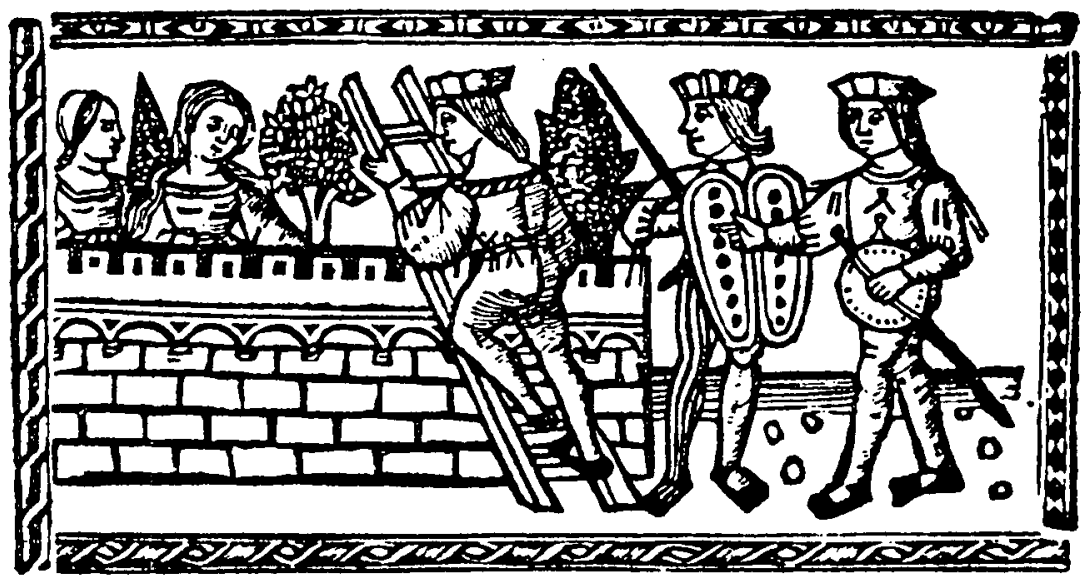

Valencia 1514. Grabado del $19^{\circ}$ aucto (1). 